\title{
Cellular metabolic activity as a marker of cytotoxicity and immunotropicity of probiotics' derivatives
}

\author{
O. V. Knysh*, O. Y. Isayenko*, O. V. Falko**, Y. M. Babych*, \\ V. Y. Prokopyuk**, O. S. Prokopyuk**, M. S. Pogorila* \\ *SI “I. I. Mechnikov Institute of Microbiology and Immunology of National Academy of Medical Sciences of Ukraine”, \\ Kharkiv, Ukraine \\ ${ }^{* *}$ Institute for Problems of Cryobiology and Cryomedicine, National Academy of Sciences of Ukraine, Kharkiv, Ukraine
}

Article info

Received 29.03.2018

Received in revised form 03.05.2018

Accepted 11.05.2018

SI "I. I. Mechnikov Institute of Microbiology and Immunology of National Academy of Medical Sciences of Ukraine", Pushkins'ka st., 14/16, Kharkiv, 61057, Ukraine. Tel: + +38-068-210-47-10. E-mail: knysh_oksana@ukr.net

Institute for Problems of Cryobiology and Cryomedicine, National Academy of Sciences of Ukraine, Pereyaslavs'ka st. 23, Kharkiv, 61015, Ukraine.
Knysh, O. V., Isayenko, O. Y., Falko, O. V., Babych, Y. M., Prokopyuk, V. Y., Prokopyuk, O. S., \& Pogorila, M. S. (2018). Cellular metabolic activity as a marker of cytotoxicity and immunotropicity of probiotics' derivatives. Regulatory Mechanisms in Biosystems, 9(2), 223-228. doi:10.15421/021833

Structural components of cells and metabolites of probiotics with biologically active potential, along with the study of effectiveness, require a series of tests to ensure their safety. The study aims to test the cytotoxicity and potential of structural and metabolic derivatives of Bifidobacterium bifidum and Lactobacillus reuteri to affect the immunocompetent cells using in vitro tests that characterize the metabolic activity of test-cells. Structural components of probiotic bacteria were obtained by the physical method of disintegration - cyclic freezing-thawing. Metabolic derivatives were obtained by cultivation of producers - bifidobacteria and lactobacilli in their own disintegrates. Cultures of mouse embryonic fibroblasts and splenocytes were used as the test cells. MTT and Alamar Blue ${ }^{\circledR}$ were used as redox indicators. According to the MTT test, filtrates that contain structural and metabolic derivates at a concentration of $5 \%$ and $10 \%$ in the incubation medium did not cause significant changes in the metabolic activity of the embryonic mouse fibroblasts. An increase of up to $20 \%$ of content in the incubation medium of filtrates of lactobacilli disintegrates led to a reduction of metabolic activity of test cells by 52.7 $\pm 6.2 \%$, of filtrates of bifidobacteria disintegrates - by $26.5 \pm 6.5 \%$, of filtrates of lactobacterium culture - by $15.7 \pm 6.9 \%$, of filtrates of bifidobacterium cultures - by $40.4 \pm 6.8 \%$. According to the Alamar Blue ${ }^{\circledR}$ test, filtrates that contained only structural derivatives of lactobacilli and bifidobacteria at concentrations of $5 \%$ and $10 \%$, as well as filtrates that contained a complex of structural and metabolic derivatives at a concentration of 5\%, did not cause significant changes in the reducing ability of mouse splenocytes. At concentrations of $10 \%$, filtrate containing a complex of structural and metabolic derivatives of lactobacilli, caused the inhibition of metabolic activity of splenocytes by $14.6 \pm 3.5 \%$, and bifidobacteria - by $10.0 \pm 2.8 \%$. With the contents of the incubation medium at $20 \%$ concentration, the filtrate of the disintegrates of lactobacilli decreased the metabolic activity of splenocytes by $12.2 \pm 3.0 \%$, and the filtrate of lactobacillus cultures that were grown on their own disintegrates - by $43.2 \pm 3.3 \%$. Increasing the content of the disintegrate filtrate and the bifidobacteria culture that were grown on their own disintegrates in the culture medium by up to $20 \%$ led to a decrease the metabolic activity of splenocytes by $38.0 \pm 2.0 \%$. Thus, the research has shown: the orientation of changes in cellular metabolism under the influence of the studied biologically active derivatives is similar in all model systems, and their intensity depends on the type of test cells, regenerative substrates and concentration of the agent of influence in model systems. The obtained results stimulate further exploration of the immunotropicity of the investigated derivatives of probiotic bacteria and can be used for development of new immunobiological preparations.

\section{Метаболічна активність клітин як маркер цитотоксичності та імунотропності дериватів пробіотиків}

\author{
О. В. Книш*, О. Ю. Ісаєнко*, О. В. Фалько**, Є. М. Бабич*, \\ В. Ю. Прокопюк**, О. С. Прокопюк**, М. С. Погоріла*
}

*Державна установа «Інститут мікробіології та імунології ім. І. І. Мечникова Національної академії медичних наук Украӥни», Харків, Україна

**Інститут проблем кріобіологї̈ та кріомедицини Національної академії наук України, Харків, Україна

Структурні компоненти клітин і метаболіти пробіотиків, що володіють біологічно активним потенціалом, поряд із дослідженням ефективності вимагають проведення низки випробувань безпечності їх застосування. Вивчали цитотоксичність та потентність до впливу 
на імунокомпетентні клітини структурних і метаболітних дериватів Bifidobacterium bifidum і Lactobacillus reuteri за допомогою тестів in vitro, що характеризують метаболічну активність клітин. Структурні компоненти пробіотичних бактерій отримані методом фізичної дезінтеграції - циклічного заморожування- відігрівання. Метаболітні похідні одержані шляхом культивування продуцентів (біфідобактерій та лактобактерій) у власних дезінтегратах. Культури ембріональних фібробластів і спленоцитів мишей використані як тест-клітини, а МТТ та Alamar Blue ${ }^{\circledR}$ - редокс-індикатори. За даними MTТ-тесту, фільтрати, що містять структурні та метаболітні деривати, за умови вмісту в середовищі інкубації в концентрації 5\% та 10\%, не викликають суттєвих змін метаболічної активності ембріональних фібробластів миші. Збільшення вмісту в інкубаційному середовищі фільтратів дезінтегратів лактобактерій до 20\% знижує метаболічну активність тест-клітин на $52,7 \pm 6,2 \%$, фільтратів дезінтегратів біфідобактерій - на 26,5 $\pm 6,5 \%$, фільтратів культур лактобактерій - на $15,7 \pm 6,9 \%$, фільтратів культур біфідобактерій - на 40,4 \pm 6,8\%. За даними Alamar Bluе ${ }^{\circledR}$-тесту, фільтрати, що містять лише структурні деривати лакто- та біфідобактерій, у концентрації 5\% та 10\%, а також фільтрати, що містять комплекс структурних і метаболітних дериватів у концентрації 5\%, не спричиняють значних змін відновлювальної здатності спленоцитів миші. За концентрації 10\% фільтрати, що містять структурні та метаболітні деривати лактобактерій, викликають пригнічення метаболічної активності спленоцитів на 14,6 $\pm 3,5 \%$, а деривати біфідобактерій - на 10,0 \pm 2,8\%. За вмісту в середовищі інкубації в концентрації 20\% фільтрати дезінтегратів лактобактерій викликають пригнічення метаболічної активності спленоцитів на 12,2 \pm 3,0\%, а фільтрати культур лактобактерій, вирощених у власних дезінтегратах, на 43,2 + 3,3\%. Підвищення вмісту в інкубаційному середовищі фільтратів дезінтегратів та культур біфідобактерій, що виросли у власних дезінтегратах, до 20\% знижує метаболічну активність спленоцитів на $38,0 \pm 2,0 \%$. Таким чином, спрямованість змін клітинного метаболізму за впливу досліджуваних білогічно активних дериватів подібна в усіх модельних системах, а їх інтенсивність залежить від виду тест-клітин, відновлюваних субстратів і концентрації агентів впливу в модельних системах. Отримані результати спонукають до подальшого вивчення імунотропності досліджуваних дериватів пробіотичних бактерій і можуть бути використані для розроблення нових імунобіологічних препаратів.

Ключові слова: метаболічна активність; проліферація лімфоцитів; ембріональні фібробласти миші; спленоцити миші

\section{Ветуп}

Нові речовини та сполуки штучного та природного походження, а також створені на їх основі лікувально-профілактичні засоби потребують як експериментального доклінічного випробування щодо певних біологічних властивостей, так і проведення токсикологічних досліджень (Stefanov, 2001; Habriev, 2005). Розроблення препаратів нового покоління на основі бактеріальних похідних структурних компонентів і продуктів життєдіяльності пробіотичних мікроорганізмів - метабіотиків, які мають низку переваг порівняно $з$ клітинними препаратами, наразі перспективне й актуальне (Shenderov, 2013; Shaikh \& Sreeja, 2017; Shenderov \& Gabrichevsky, 2017). Метаболіти пробіотичних мікроорганізмів мають стимулювальний вплив на нормальну мікрофлору (Rivière et al., 2016), виявляють протимікробну (Lew \& Liong, 2013; Presti et al., 2015; Sharma et al., 2017), імуномодуляторну (Jensen et al., 2010; Bauer et al., 2013; Kang \& Connolly, 2016), протизапальну (Griet et al., 2014; Richards et al., 2016; Castiblanco et al., 2017), противірусну (Kim et al., 2014; Ang et al., 2016; Al Kassaa, 2017), протипухлинну (Sharma \& Shukla, 2016) та інші види активності. Структурні компоненти бактеріальних клітин - фрагменти клітинних стінок, рибосоми, нуклеїнові кислоти відносять до біологічно активних речовин імунотропної дії завдяки здатності викликати рецептор-опосередковані каскадні реакції, результат яких - активація механізмів імунного захисту організму (Ashraf \& Shah, 2013; Kozlov \& Andronova, 2013; Fong et al., 2015). Одержують клітинні структури за допомогою різних способів дезінтеграції: хімічних, фізичних, механічних і комбінованих (Bauer et al., 2010; Kim et al., 2014; Kang \& Connolly, 2016). Метаболіти отримують шляхом культивування у поживному середовищі продуцента та наступного його видалення (Griet et al., 2014; Castiblanco et al., 2017). При цьому повністю очистити кінцевий метаболітумісний продукт від поживного середовища практично не можливо. Ми розробили спосіб одержання біологічно активних дериватів бактерій пробіотичних штамів, який дозволяє уникнути застосування поживних середовищ і об'єднати розрізнені процедури отримання структурних компонентів бактеріальних клітин та їх метаболітів в один двоетапний процес (Knysh et al., 2018). Необхідність проведення токсикологічних досліджень дериватних продуктів, що містять структурні та метаболітні похідні пробіотиків, зумовлена перспективністю їх використання під час розроблення нових імунобіологічних препаратів.

Прийнятими в Україні та світі етико-правовими та законодавчими нормами - Директивою 2010/63/СС, Законом України «Про захист тварин від жорстокого поводження» № 3447-IV 2006 року та «Свропейською конвенцією про захист хребетних тварин», до якої 2 травня 2017 року приєдналася Україна, затверджено обмеження щодо застосування тварин для дослідних та інших наукових цілей і необхідність заміни класичних досліджень in vivo адек- ватними альтернативними методами: тестуванням на тканинних та клітинних культурах, математичним моделюванням, комп'ютерними технологіями та іншими тестами. Серед таких методів оцінювання токсичності різних сполук і нових препаратів найпоширенішими стали методи із застосуванням біологічних систем, отриманих від тварин, метаболічні ланцюги яких наближені до таких у людини. Вони дають можливість знизити вартість, скоротити терміни та підвищити надійність доклінічних досліджень (Davila et al., 1998; Arora et al., 2011; Adan et al., 2016). Використання клітинних культур дозволяе виявити прямий цитотоксичний ефект досліджуваних речовин за змінами морфологічних показників, проліферації або метаболічної активності клітин. Відображенням деяких аспектів загального метаболізму та маркером життєздатності клітин може служити їх здатність до відновлення редокс-індикаторів - резазурину та солей тетразолію. Такі індикатори після інкубації з популяцією клітин перетворюються на забарвлені або флуоресцентні кінцеві продукти, вміст яких визначається кількісно та пропорційний кількості життєздатних клітин (Rampersad, 2012; Riss et al., 2013; Präbst et al., 2017).

Колориметричний МТТ-тест - стандартний метод перевірки цитотоксичності різних сполук на етапі фармакологічного скринінгу. Він технічно простий, чутливий та відтворюваний і за певних умов відображає кількість життєздатних клітин (Riss et al., 2016; Präbst et al., 2017). У його основі - здатність безбарвної солі тетразолію ((3-[4,5-диметилтіазол-2-іл]-2,5-дифенілтетразолію бромід, МТТ) відновлюватися до забарвленого формазану за дії мітохондріальних ферментів живих клітин, частіше - адгезованих до стінок планшета. Формазан накопичується у вигляді нерозчинних преципітатів усередині, на поверхні клітин і в культуральному середовищі. Загибель клітин супроводжується втратою здатності перетворювати МТТ на забарвлений кінцевий продукт, що реєструють спектрофотометрично. Як тестові застосовують клітини різного походження, серед яких фібробласти визнані стандартним об'єктом під час доклінічних випробувань.

Також для вивчення цитотоксичності потенційних фармацевтичних препаратів і сполук застосовують резазурин-тест (Alamar Bluе ${ }^{\circledR}$-тест), який відображає відновлювальний потенціал, що проліферують (O'brien et al., 2000; Rampersad, 2012; Präbst et al., 2017). На відміну від МТТ, резазурин відновлюється більш широким спектром ферментів: мітохондріальними та цитоплазматичними дегідрогеназами, цитохромами. Життєздатні клітини 3 активним метаболізмом відновлюють резазурин у рожевий флуоресцентний продукт - резоруфін, кількість якого пропорційна кількості життєздатних клітин. Мета цієї статті - оцінити цитотоксичність структурних і метаболітних дериватів Bifidobacterium bifidum i Lactobacillus reuteri за допомогою in vitro тестів шляхом визначення метаболічної активності тест-клітин - ембріональних фібробластів і спленоцитів миші. 


\section{Матеріал і методи досліджень}

Дослідженню на цитотоксичність підлягали: фільтрати дезінтегратів біфідобактерій і лактобактерій (містять структурні компоненти бактеріальних клітин); фільтрати культур біфідобактерій і лактобактерій, вирощених на власних дезінтегратах (містять структурні компоненти та метаболіти бактеріальних клітин).

Структурні компоненти біфідо- та лактобактерій отримували шляхом застосування фізичного методу дезінтеграції бактеріальних клітин - циклічного заморожування-відтавання. Для цього ліофілізовані виробничі штами B. bifidum 1 (з препарату «Біфідумбактерин», ПрАТ «Біофарма», Україна) та L. reuteri Protectis DSM 17938 (з препарату «BioGaia», «BioGaia AB», Sweden) після регідратації культивували протягом 20-24 годин за температури $37 \pm$ $1{ }^{\circ} \mathrm{C}$ у рідкому або напіврідкому поживному середовищі (MRSбульйон, тіогліколеве середовище). Після триразового відмивання від середовища готували суспензії клітин 3 оптичною густиною 10,0 одиниць за шкалою МакФарланда за допомогою приладу Densi-La-Meter (Lachema, Чехія). Цикли заморожування-відтавання проводили десятиразово в такому режимі: заморожування - пасивним охолодженням у морозильній камері холодильника Samsung RB29FSRNDSA до температури $-23 \pm 1{ }^{\circ} \mathrm{C}$, відігрівання - на водяній бані за температури $37 \pm 1^{\circ} \mathrm{C}$ до повного відтавання.

Продукти метаболізму біфідо- та лактобактерій одержували під час вирощування пробіотиків у власних дезінтегратах. Для цього мікробну суспензію бактерій з оптичною густиною 10 одиниць за шкалою МакФарланда вносили в дезінтеграт у співвідношенні $1: 9$ і культивували за температури $37 \pm 1^{\circ} \mathrm{C}$ упродовж 72 годин (Knysh et al., 2018).

Отримані дезінтеграти та культури, які виросли в дезінтегратах, для видалення цілих клітин та клітинного дебрису, спочатку піддавали центрифугуванню за 1100 g упродовж 15 хвилин, після чого супернатант фільтрували через стерильні мембранні фільтри 3 діаметром пор 0,2 мкм (Владіпор, Росія).

Експерименти з використанням лабораторних тварин проводили відповідно до Закону України «Про захист тварин від жорстокого поводження» (№ 3447-IV від 21.02.2006 р.) із дотриманням вимог Комітету з біоетики Інституту, узгоджених із положенням «ЕВропейської конвенції захисту хребетних тварин, якіх використовують в експериментальних та інших наукових цілях» (Страсбург, 1986).

Культуру ембріональних фібробластів миші отримували за стандартною методикою з ембріонів мишей $\mathrm{BALB} / \mathrm{c}$, вилучених на 13-14-ту добу гестації шляхом механічної та ензиматичної гомогенізації (за допомогою 0,05\% Trypsin-EDTA) тулубів ембріонів без навколоплідних оболонок, голови та внутрішніх органів (Јоzefczuk et al., 2012). Фібробласти ресуспендували у культуральному середовищі DMEM/F12 (Sigma, Німеччина) з додаванням 10\% фетальної телячої сироватки (FCS), пеніциліну (50 од./мл) і стрептоміцину (50 мг/мл).

Визначення цитотоксичності дериват-вмісних фільтратів за МТT-тестом. Суспензію фібробластів у концентрації 100000 клітин/мл вносили у лунки 96-лункового планшета (Tecan Genios, Tecan Inc., Австралія) по 100 мкл, культивували в $\mathrm{CO}_{2}$ інкубаторі (Automatic Flo-Thru $\mathrm{CO}_{2}$ Incubators) за 95\% вологості, 5\% вмісту $\mathrm{CO}_{2}$ та температури $37 \pm 1^{\circ} \mathrm{C}$. Через 24 години неприкріплені до пластику клітини видаляли, а прикріплену фракцію клітин культивували до отримання конфлюентного шару. Після формування моношару клітини двічі промивали середовищем DMEM/F12 без сироватки. У дослідні лунки вносили середовище DMEM/F12 3 досліджуваними фільтратами у кінцевій концентрації 5\%, 10\% та $20 \%$ об., у контрольні - середовище без досліджуваного фільтрату (негативний контроль, К). Планшети інкубували за вищезазначених умов протягом 24 годин. МТТ-реагент (безбарвну сіль тетразолію [3-(4,5-dimethylthiazol-2yl)-2,5-diphenyltetrazolium bromide], Sigma Chemical Co., USA) додавали в лунки по 15 мкл. Інкубували 3 ним клітини упродовж 4 годин в $\mathrm{CO}_{2}$ інкубаторі в умовах, сприятливих для відновлення клітинами розчинного МТТ-реагенту до нерозчинного формазану. Після закінчення зазначеного часу з лунок видаляли середовище та вносили по 100 мкл диметилсуль- фоксиду (ДМСО) з метою солюбілізації формазану. Акуратно струшували планшет протягом 5-10 хвилин до розчинення кристалів формазану.

За допомогою планшетного ридера (Elise microplate reader with PC software UTRAO SM 600, China) визначали оптичну густину кожної лунки за 530 нм, віднімали виміряне фонове поглинання за 620 нм. Результати розраховували за формулою (RAU = оптична густина зразка 3 клітинами - оптична густина зразка без клітин) i наводили у відсотках від значень, отриманих для контрольного зразка.

Отримання спленоцитів миші. Селезінку мишей BALB/c (3 самця, віком 6-8 тижнів, вагою 18-20 г) отримували в асептичних умовах. Виділену селезінку одноразово промивали 70\% етиловим спиртом і тричі середовищем RPMI-1640 (Biowest), після чого подрібнювали пінцетами до стану однорідної маси, переносили у пластикову пробірку ємністю 15 мл, вносили 4 мл середовища RPMI-1640 з додаванням 10\% ембріональної сироватки крові великої рогатої худоби $\left(37^{\circ} \mathrm{C}\right)$, центрифугували за $500 \mathrm{~g}$ (1500 об./хв) протягом 5 хвилин. Супернатант видаляли, осад ресуспендували в 1 мл культурального середовища RPMI з додаванням 10\% фетальної телячої сироватки (FCS), пеніциліну (50 од./мл) i стрептоміцину (50 мг/мл). Концентрацію клітин визначали за допомогою гемоцитометра Marienfeld.

Визначення ичитотоксичності дериват-вмісних фільтратів за Alamar Blue ${ }^{\circledR}$-тестом. Суспензію спленоцитів вносили в лунки пластикового планшета Tecan Genios (Tecan Inc., Австралія) по 80 мкл (70 000 клітин на лунку). У дослідні лунки додавали по 20 мкл досліджуваних фільтратів (нерозведених і розведених $1: 2$; $1: 4$ культуральним середовищем). Кінцеві концентрації фільтратів у лунках склали відповідно 20\%, 10\% та 5\%об. Контрольні лунки містили спленоцити у середовищі культивування (негативний контроль, К). Клітинні суспензії культивували в інкубаторі за $5 \%$ концентрації $\mathrm{CO}_{2}, 95 \%$ вологості та температури $37 \pm 1{ }^{\circ} \mathrm{C}$ упродовж 24 годин. Alamar Blue ${ }^{\circledR}$ (Serotec Ltd, США) вносили у лунки в концентрації 0,15 мг/мл, після чого планшети витримували упродовж двох годин в інкубаторі у зазначених умовах. Кількість відновленого флуоресцентного барвника у зразках визначали за інтенсивністю флуоресценції за довжини хвилі збудження 550 та емісії 590 нм. Вимірювання проводили за допомогою ридера (Elise microplate reader with PC software UTRAO SM 600, China). Результати вимірювань розраховані за формулою (RFU = інтенсивність флуоресценції зразка 3 клітинами - інтенсивність флуоресценції зразка без клітин) і наведені у відсотках відносно контрольного зразка, що не містить досліджуваних речовин.

Статистичну обробку отриманих результатів проводили з використанням програми Statistica 8.0 (StatSoft Inc., USA). Для кожної концентрації досліджуваних речовин експерименти виконано тричі у шести повторах. Для виявлення розбіжностей між вибірками застосовано непараметричний U-критерій Манна-Уїтні. Отримані дані наведені у вигляді середнього арифметичного (х) зі стандартним відхиленням (SD). Значення $\mathrm{P}<0,05$ прийняті як статистично значущі.

\section{Результати}

За результатами МТТ-тесту, присутність у середовищі інкубації ембріональних фібробластів миші фільтратів, що містять структурні та метаболітні деривати лактобактерій, у концентрації $5 \%$ та $10 \%$ не викликає статистично достовірних змін метаболічної активності тест-клітин (рис. 1). Введення до складу середовища фільтрату дезінтеграту лактобактерій у концентрації 20\% спричиняє значне пригнічення відновлювальної здатності фібробластів: іï показник знижується на 52,7 $\pm 6,2 \%$ порівняно 3 контролем. Метаболічна активність фібробластів за $20 \%$ вмісту в середовищі інкубації фільтрату культури лактобактерій, вирощеної у власному кріодезінтеграті, знижується на $15,7 \pm 6,9 \%$. Таким чином, відновлювальна здатність фібробластів під час застосування як редокс-індикатора МТТ виявилася чутливішою до впливу структурних, ніж комплексу структурних і метаболітних дериватів лактобактерій. 


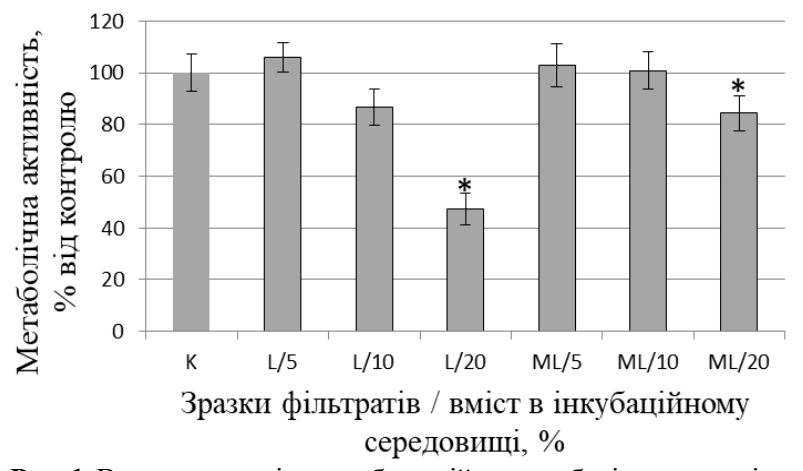

Рис. 1. Вплив дериватів лактобактерій на метаболічну активність ембріональних фібробластів миші, визначену за МТТ-тестом

$(\mathrm{x} \pm \mathrm{SD}, \mathrm{n}=3)$ : $\mathrm{L}$ - фільтрати дезінтегратів лактобактерій;

$\mathrm{ML}$ - фільтрати культур лактобактерій, вирощених на власних дезінтегратах; * - відмінності статистично достовірні за $\mathrm{P}<0,05$ порівняно $з$ контролем

Фільтрати, що містять структурні та метаболітні деривати біфідобактерій, у концентрації 5\% та $10 \%$ не викликають статистично достовірних змін метаболічної активності ембріональних фібробластів миші за МТТ-тестом (рис. 2). За концентрації в середовищі культивування фільтратів 5\% спостерігається тенденція до підвищення відновної здатності фібробластів. Збільшення вмісту фільтратів дезінтегратів біфідобактерій у середовищі культивування до 20\% супроводжується суттєвим пригніченням метаболічної активності тест-клітин: iï рівень знижується на $26,5 \pm 6,5 \%$. Фільтрати культур біфідобактерій, вирощених у власних дезінтегратах, за вмісту в середовищі культивування $20 \%$ спричиняють значне зниження відновної здатності ембріональних фібробластів миші: порівняно 3 контрольними показниками відновний потенціал тест-клітин зменшується на $40,4 \pm 6,8 \%$. Отримані результати МТТ-тесту показують, що за однакового вмісту в інкубаційному середовищі (20\%) структурні деривати біфідобактерій спричиняють менш суттєве пригнічення метаболічної активності фібробластів, ніж комплекс структурних і метаболітних дериватів.

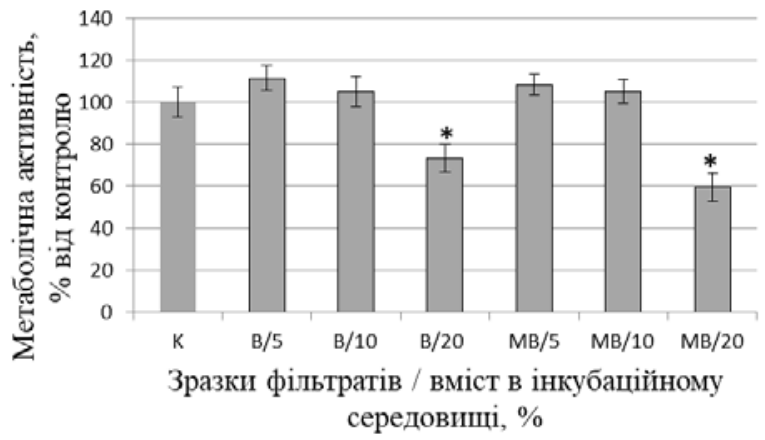

Рис. 2. Вплив дериватів біфідобактерій на метаболічну активність ембріональних фібробластів миші, визначену за МТТ-тестом $(\mathrm{x} \pm \mathrm{SD}, \mathrm{n}=3): B$ - фільтрати дезінтегратів біфідобактерій; $M B$ - фільтрати культур біфідобактерій, вирощених на власних дезінтегратах; * - відмінності статистично достовірні за $\mathrm{P}<0,05$ порівняно з контролем

Як видно 3 наведених на рисунку 3 даних, вміст у середовищі інкубації фільтратів дезінтегратів у концентрації 5\% і 10\% та фільтратів культур лактобактерій, вирощених у власних дезінтегpaтax, у концентрації 5\% не викликає статистично достовірних змін метаболічної активності спленоцитів миші за результатами Alamar Blue ${ }^{\circledR}$-тесту. Присутність в інкубаційному середовищі дезінтегратів лактобактерій у концентрації $20 \%$ спричиняє статистично достовірне зниження метаболічної активності тест-клітин порівняно 3 контролем (на $12,2 \pm 3,0 \%$ ). Фільтрати культур лактобактерій, вирощених на власних дезінтегратах, у концентрації 10\% викликають статистично достовірне зниження метаболічної ак- тивності спленоцитів миші на $14,6 \pm 3,5 \%$, а в концентрації $20 \%$ на $43,2 \pm 3,3 \%$ порівняно $з$ контрольними показниками. Таким чином, за результатами Alamar Blue ${ }^{\circledR}$-тесту, суттєвіше пригнічення метаболічної активності спленоцитів миші відбувається за дії комплексу структурних і метаболітних порівняно з аналогічним ефектом, викликаним дією структурних дериватів лактобактерій.

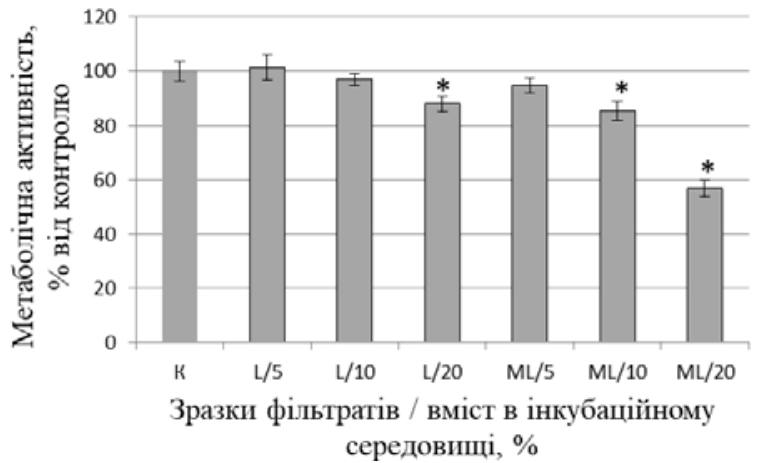

Рис. 3. Вплив дериватів лактобактерій на метаболічну активність спленоцитів миші, визначену за Alamar Blue ${ }^{\circledR}$-тестом

( $\pm \mathrm{SD}, \mathrm{n}=3): L-$ фільтрати дезінтегратів лактобактерій;

$M L$ - фільтрати культур лактобактерій, вирощених на власних дезінтегратах; ${ }^{*}$ - відмінності статистично достовірні за $\mathrm{P}<0,05$ порівняно $з$ контролем

Результати дослідження впливу дериватів біфідобактерій на метаболічну активність спленоцитів миші в Alamar Blue ${ }^{\circledR}$-тесті дозволили зробити висновок про те, що всі досліджувані дериватумісні фільтрати за концентрації в інкубаційному середовищі 5\% та фільтрати дезінтегратів біфідобактерій за концентрації $10 \%$ не викликають статистично достовірних змін метаболізму тест-клітин (рис. 4). За умови 20\% вмісту в середовищі інкубації фільтратів дезінтегратів біфідобактерій метаболічна активність тест-клітин пригнічується на $38,2 \pm 2,0 \%$ порівняно $з$ контролем. Уведення в середовище інкубації спленоцитів фільтратів культур біфідобактерій, вирощених у власних дезінтегратах, в концентрації $10 \%$ пригнічує метаболічну активність спленоцитів на $10,0 \pm 2,8 \%$, а в концентрації 20\% - на $38,0 \pm 2,1 \%$ порівняно з контрольними показниками. Отже, за даними Alamar Blue ${ }^{\circledR}$-тесту, за дії комплексу структурних і метаболітних дериватів біфідобактерій відбувається таке саме за інтенсивністю пригнічення метаболічної активності спленоцитів миші, як і за дії структурних дериватів біфідобактерій.

\section{Обговорення}

Отримані дані щодо впливу дериватів лактобактерій на метаболічну активність ембріональних фібробластів миші добре узгоджуються з результатами аналогічних досліджень, які показали відсутність цитотоксичного впливу суміші фільтратів культуральних рідин двох штамів L. reuteri (ATCC PTA 5298 та DSM 17938) на життєздатність гінгівальних фібробластів із застосуванням MTTтесту (Castiblanco et al., 2017). Слід зазначити, що вміст метаболітів лактобактерій в інкубаційному середовищі, досліджений авторами, значно нижчий, ніж обраний нами, за рахунок розведення безклітинного супернатанта до концентрації, еквівалентної тій, що виробляється бактеріями у кількості від 0,5 до 5,0 × $10^{7}$ КУО/мл. Інші автори (Sultana et al., 2013) показали, що лізат L. reuteri ATCC 55730 (отриманий із $1 \times 10^{8} \mathrm{KУО/мл} \mathrm{бактерій)} \mathrm{не} \mathrm{впливає} \mathrm{на}$ життєздатність нормальних епідермальних кератиноцитів людини, визначену за допомогою МТТ-тесту. Відсутність цитотоксичного ефекту фільтратів ультразвукових дезінтегратів іншого виду лактобактерій - L. ruminis відносно клітин HeLa за допомогою МТТ-тесту встановили Kim et al. (2014). Концентрація клітин, підданих дезінтеграції, відповідала обраній у нашому дослідженні. Вміст фільтрату в середовищі культивування тестклітин становив $10 \%$ (у наших експериментах - 5\% та 20\%). Під час дослідження впливу різних компонентів лактобактерій $(L$. gasseri та L. crispatus): культуральних супернатантів, 
цитоплазматичних екстрактів, екстрактів клітинних стінок і живих клітин на проліферативну активність нормальних та пухлинних (HeLa) цервікальних фібробластоподібних клітин за допомогою MTТ-тесту виявлено наявність цитотоксичної дії відносно пухлинних та відсутність - нормальних клітин (Motevaseli et al., 2013).

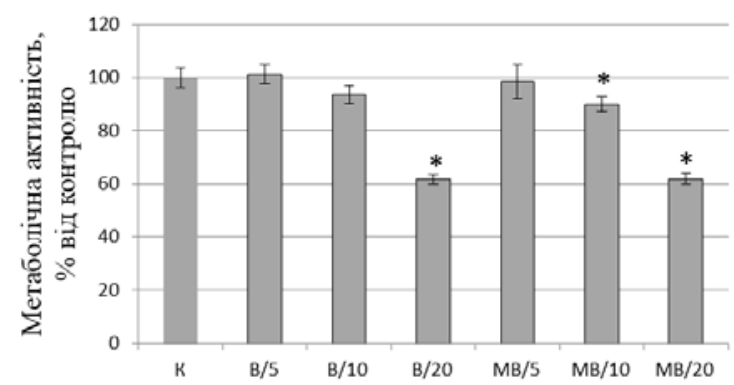

Зразки фільтратів / вміст в інкубаційному середовищі, \%

Рис. 4. Вплив дериватів біфідобактерій на метаболічну активність спленоцитів миші, визначену за Alamar Blue ${ }^{\circledR}-$ тестом $(x \pm S D, n=3)$ : $B$ - фільтрати дезінтегратів біфідобактерій; $M B$ - фільтрати культур біфідобактерій, вирощених на власних дезінтегратах; * - відмінності статистично достовірні за $\mathrm{P}<0,05$ порівняно з контролем

Одержані дані щодо впливу дериватів біфідобактерій на метаболічну активність ембріональних фібробластів миші подібні до повідомлених іншими авторами результатів аналогічних досліджень. Цитотоксичність клітинних похідних різних штамів біфідобактерій за допомогою МТТ-тесту дослідили Kim et al. (2014). Автори показали, що 10\% вміст у середовищі культивування тестклітин фільтратів ультразвукових дезінтегратів біфідобактерій не спричиняє цитотоксичної дії відносно клітин HeLa. Схожі результати також навели Sultana et al. (2013): лізат B. longum ATCC 51870 (отриманий $310^{8} \mathrm{KУO} /$ мл бактерій) не пливає на метаболічну активність нормальних епідермальних кератиноцитів людини, визначену за допомогою МТТ-тесту. Залежність ефекту екстракту B. adolescentis SPM0212, що містить структурні компоненти біфідобактерій, від виду тест-клітин, виявили Lee et al. (2008). Цитотоксична дія спостерігається відносно ракових клітин епітелію товстого кишечника та відсутня відносно не вражених неопластичним процесом епітеліальних клітин.

Низка авторів застосували Alamar Blue ${ }^{\circledR}$-тест для оцінювання здатності спленоцитів до проліферації за дії похідних лактобактеpiй (Bauer et al., 2010; Kang et al., 2016). При цьому автори мали на увазі, що зміни метаболічної активності клітин - це відображення зміни їх проліферативної активності та маркер імунотропності досліджуваних речовин. Під час вивчення впливу лізатів (400-500 мг/мл) та супернатантів L. reuteri ATCC 55730 (що культивували в середовищі MRS із $50 \mathrm{mM}$ гліцерином і без нього) на проліферативну активність лімфоцитів селезінки мишей BALB/с установлено, що лізати та супернатанти, отримані після культивування L. reuteri за відсутності гліцерину, викликають незначну дозозалежну стимуляцію проліферації лімфоцитів (Kang et al., 2016). Стимулювальний ефект супернатантів, отриманих після культивування лактобактерій за присутності гліцерину, значно перевищував навіть ефект відомих мітогенів - конкаваліну А, міогену лаконоса, фітогемаглютиніну та ліпополісахариду. Імуностимулювальний ефект екстрактів лактобактерій (L. fermentum, L. rhamnosus) на спленоцити мишей виявили під час застосування Alamar Blue ${ }^{\circledR}$ тесту також інші дослідники (Bauer et al., 2010).

Дослідження цитотоксичності живих L. reuteri Protectis DSM 17938 відносно клітин рабдоміосаркоми (RD) та епітеліальної колоректальної аденокарциноми (Сасо-2) із застосуванням резазурин-тесту показало, що годинна інкубація тест-клітин із живими лактобактеріями $\left(10^{11} \mathrm{KУO}\right)$ не викликає значної втрати їх життєздатності (Ang et al., 2016).

Вивчення впливу різних фракцій цитоплазматичних пептидів та білків B. lactis виявило стимулювальний вплив похідних на про- ліферативну активність спленоцитів у разі застосування Alamar Blue $^{\circledR}$ як маркера клітинної проліферації (Amrouche et al., 2006). Вираженість стимулювального впливу залежала від фракції та мала концентраційнозалежний характер. Стимулювальний ефект дозволив авторам зробити висновок, що досліджені білково-пептидні фракції біфідобактерій імунологічно активні.

Порівнюючи отримані у цій статті дані та результати досліджень впливу дериватів лакто- та біфідобактерій на метаболічну активність спленоцитів миші із застосуванням Alamar Blue ${ }^{\circledR}$-тесту інших авторів (Amrouche et al., 2006; Bauer et al., 2010; Kang et al., 2016), ми дійшли висновку: ефект похідних пробіотичних бактерій залежить від штаму, умов культивування пробіотика, способу отримання та біохімічного складу кінцевого продукту. Різноспрямований характер впливу дериватумісних продуктів на спленоцити у нашому (пригнічення) та вищезазначених дослідженнях (стимуляція) можна пояснити, спираючись на фундаментальну біомедичну парадигму гормезису, згідно з якою малі дози стимулюють, а великі інгібують біологічні показники (Shafran et al., 2010). Ймовірно, для отримання стимулювального впливу на спленоцити необхідне застосування менших доз випробуваних нами дериват-умісних фільтратів, що планується перевірити у подалыших дослідженнях.

\section{Висновки}

Незважаючи на застосування в цій роботі модельних систем, що відрізняються використанням різних за морфофункціональними властивостями тест-клітин і субстратних речовин для ферментативного відновлення, характер впливу досліджуваних дериватумісних фільтратів на метаболічну активність тест-клітин подібний. Інтенсивність впливу досліджуваних похідних пробіотичних бактерій на метаболічну активність тест-клітин має залежність від концентрації дериватного продукту у середовищі інкубації та складу модельної системи (тест-клітин і редокс-індикатора). Уміст фільтратів дезінтегратів лакто- та біфідобактерій в інкубаційному середовищі 5\% та $10 \%$ суттєво не впливає на метаболічну активність ембріональних фібробластів і спленоцитів миші. Підвищення вмісту зазначених фільтратів у інкубаційному середовищі до 20\% супроводжується статистично достовірним зниженням метаболічної активності тест-клітин. Фільтрати, які містять структурні та метаболітні деривати пробіотиків, у концентрації 5\% не викликають значних змін метаболічної активності обох видів тестклітин. Концентрація зазначених фільтратів у середовищі інкубації 10\% не впливає на метаболічну активність ембріональних фібробластів, але спричиняє зниження відновного потенціалу спленоцитів миші. Підвищення вмісту в середовищі інкубації фільтратів культур пробіотиків, вирощених у власних дезінтегратах, до 20\% супроводжується значним пригніченням метаболічної активності ембріональних фібробластів та спленоцитів миші.

Отримані результати дослідження цитотоксичності біологічно активних дериватів B. bifidum та L. reuteri спонукають до подальшого вивчення імунотропності досліджуваних дериватів пробіотичних бактерій і можуть бути використані для розроблення нових імунобіологічних препаратів дериватного типу.

\section{References}

Adan, A., Kiraz, Y., \& Baran, Y. (2016). Cell proliferation and cytotoxicity assays. Current Pharmaceutical Biotechnology, 17(14), 1213-1221.

$\mathrm{Al}$ Kassaa, I. (Ed.). (2017). The antiviral activity of probiotic metabolites. In: New insights on antiviral probiotics. Springer, Cham.

Amrouche, T., Boutin, Y., \& Fliss, I. (2006). Effects of bifidobacterial cytoplasm peptide and protein fractions on mouse lymphocyte proliferation and cytokine production. Food and Agricultural Immunology, 17(1), $29-42$.

Ang, L. Y. E., Too, H. K. I., Tan, E. L., Chow, T. K. V., Shek, P. C. L., Tham, E., \& Alonso, S. (2016). Antiviral activity of Lactobacillus reuteri protectis against Coxsackievirus A and Enterovirus 71 infection in human skeletal muscle and colon cell lines. Virology Journal, 13(1), 111.

Arora, T., Mehta, A. K., Joshi, V., Mehta, K. D., Rathor, N., Mediratta, P. K., \& Sharma, K. K. (2011). Substitute of animals in drug research: An approach towards fulfillment of 4R's. Indian Journal of Pharmaceutical Sciences, 73(1), 1. 
Ashraf, R., \& Shah, N. P. (2013). Immune system stimulation by probiotic microorganisms. Critical Reviews in Food Science and Nutrition, 54(7), 938-956.

Bauer, J. A., Salvagni, M., Vigroux, J. P. L., Chalvet, L. L. G., \& Chiavaroli, C. (2010). Immunomodulatory extracts from Lactobacillus bacteria and methods of manufacturing and use thereof. U.S. Patent No 20100055082A1. U.S. Patent and Trademark Office, Washington.

Castiblanco, G. A., Yucel-Lindberg, T., Roos, S., \& Twetman, S. (2017). Effect of Lactobacillus reuteri on cell viability and PGE2 production in human gingival fibroblasts. Probiotics and Antimicrobial Proteins, 9(3), 278-283.

Davila, J. C., Rodriguez, R. J., Melchert, R. B., \& Acosta, J. D. (1998). Predictive value of in vitro model systems in toxicology. Annual Review of Pharmacology and Toxicology, 38(1), 63-96.

Fong, F. L. Y., Shah, N. P., Kirjavainen, P., \& El-Nezami, H. (2015). Mechanism of action of probiotic bacteria on intestinal and systemic immunities and antigen-presenting cells. Intemational Reviews of Immunology, 35(3), 179-188.

Griet, M., Zelaya, H., Mateos, M. V., Salva, S., Juarez, G. E., Font de Valdez, G. Villena, J., Salvador, G. A., \& Rodriguez, A. V. (2014). Soluble factors from Lactobacillus reuteri CRL1098 have anti-inflammatory effects in acute lung injury induced by lipopolysaccharide in mice. PLoS One, 9(10), e110027.

Habriev, R. U. (2005). Rukovodstvo po eksperimental'nomu (doklinicheskomu) izucheniju novyh farmakologicheskih veshhestv [Manual on experimental (preclinical) study of new pharmacological substances]. Medicina, Moscow (in Russian).

Jensen, G. S., Benson, K. F., Carter, S. G., \& Endres, J. R. (2010). GanedenBC $30^{\mathrm{TM}}$ cell wall and metabolites: anti-inflammatory and immune modulating effects in vitro. BMC Immunology, 11(1), 15.

Jozefczuk, J., Drews, K., \& Adjaye, J. (2012). Preparation of mouse embryonic fibroblast cells suitable for culturing human embryonic and induced pluripotent stem cells. Journal of Visualized Experiments, 64.

Kang, H. J., \& Connolly, E. (2016). Method of improving immune function in mammals using lactobacillus strains with certain lipids. U.S. Patent No 2016/0287702 A1. U.S. Patent and Trademark Office, Washington.

Kim, M. J., Lee, D. K., Park, J. E., Park, I. H., Seo, J. G., \& Ha, N. J. (2014). Antiviral activity of Bifidobacterium adolescentis SPM1605 against Coxsackievirus B3. Biotechnology and Biotechnological Equipment, 28(4), 681-688.

Knysh, O. V., Isajenko, O. J., Babych, J. M., Poljans'ka, V. P., Zachepylo, S. V., Kompanijec', A. M., \& Gorbach, T. V. (2018). Sposib oderzhannja biologichno aktyvnyh deryvativ bakterij probiotychnyh shtamiv [Method for obtaining biologically active derivatives of bacteria of probiotic strains]. Patent of Ukraine for useful model No 122859. Derzhavne Patentne Vidomstvo Ukrainy, Kyiv (in Ukrainian).

Kozlov, I. G., \& Andronova, T. M. (2013). Lekarstvennyye vozdeystviya cherez retseptory vrozhdennogo immuniteta [Effect of medicines via innate immunity receptors]. Allergologiya i Immunologiya, 14(4), 254-259 (in Russian).

Lee, D. K., Jang, S., Kim, M. J., Kim, J. H., Chung, M. J., Kim, K. J., \& Ha, N. J. (2008). Anti-proliferative effects of Bifidobacterium adolescentis SPM0212 extract on human colon cancer cell lines. BMC Cancer, 8(1), 310.

Lew, L. C., \& Liong, M. T. (2013). Bioactives from probiotics for dermal health: Functions and benefits. Joumal of Applied Microbiology, 114(5), 1241-1253.

Motevaseli, E., Shirzad, M., Akrami, S. M., Mousavi, A. S., Mirsalehian, A., \& Modarressi, M. H. (2013). Normal and tumour cervical cells respond differrently to vaginal lactobacilli, independent of $\mathrm{pH}$ and lactate. Journal of Medical Microbiology, 62(7), 1065-1072.
O'brien, J., Wilson, I., Orton, T., \& Pognan, F. (2000). Investigation of the Alamar Blue (resazurin) fluorescent dye for the assessment of mammalian cell cytotoxicity. The FEBS Journal, 267(17), 5421-5426.

Präbst, K., Engelhardt, H., Ringgeler, S., \& Hübner, H. (2017). Basic colorimetric proliferation assays: MTT, WST, and resazurin. In: Gilbert, D., Friedrich, O. (Eds.). Cell Viability Assays. Methods in Molecular Biology, 1601. Humana Press, New York

Presti, I., D’Orazio, G., Labra, M., La Ferla, B., Mezzasalma, V., Bizzaro, G., Giardina, S., Michelotti, A., Tursi, F., Vassallo, M., \& Di Gennaro, P. (2015). Evaluation of the probiotic properties of new Lactobacillus and Bifidobacterium strains and their in vitro effect. Applied Microbiology and Biotechnology, 99(13), 5613-5626.

Rampersad, S. N. (2012). Multiple applications of Alamar Blue as an indicator of metabolic function and cellular health in cell viability bioassays. Sensors, 12(9), 12347-12360.

Richards, J. L., Yap, Y. A., McLeod, K. H., Mackay, C. R., \& Mariño, E. (2016). Dietary metabolites and the gut microbiota: An altemative approach to control inflammatory and autoimmune diseases. Clinical and Translational Immunology, 5(5), e82.

Riss, T. L., Moravec R. A., Niles, A. L., Benink, H. A., Worzella, T. J., \& Minor, L. (2016). Cell viability assays. In: Sittampalam, G. S., Coussens, N. P., Nelson, H., Arkin, M., Auld, D., Austin, C. et al. (Eds.). Assay guidance manual. Eli Lilly \& Company, Bethesda.

Rivière, A., Selak, M., Lantin, D., Leroy, F., \& De Vuyst, L. (2016). Bifidobacteria and butyrate-producing colon bacteria: Importance and strategies for their stimulation in the human gut. Frontiers in Microbiology, 7, 979.

Shafran, L. M., Mokienko, A. V., Petrenko, N. F., Gozhenko, A. I., \& Nasibullin, B. A. (2010). K obosnovaniyu gormezisa kak fundamentalnoy biomeditsinskoy paradigmy [On the substantiation of hormesis as fundamental biomedical paradigm]. Sovremennye Problemy Toksikologii, 49-50(2-3), 13-23 (in Russian).

Shaikh, A. M., \& Sreeja, V. (2017). Metabiotics and their health benefits. International Journal of Fermented Foods, 6(1), 11-23.

Sharma, C., Singh, B. P., Thakur, N., Gulati, S., Gupta, S., Mishra, S. K., \& Panwar, H. (2017). Antibacterial effects of Lactobacillus isolates of curd and human milk origin against food-borne and human pathogens. 3 Biotechnology, 7(1), 31 .

Sharma, M., \& Shukla, G. (2016). Metabiotics: One step ahead of probiotics; an insight into mechanisms involved in anticancerous effect in colorectal cancer. Frontiers in Microbiology, 7, 1940.

Shenderov, B. A. (2013). Metabiotics: Novel idea or natural development of probiotic conception. Microbial Ecology in Health and Disease, 24(1), 20399.

Shenderov, B. A., \& Gabrichevsky, G. N. (2017). Metabiotics: An overview of progress, opportunities and challenges. International Conference on Chronic Diseases \& 6th Intemational Conference on Microbial Physiology and Genomics Brussels, Belgium, 2017. Journal of Microbial and Biochemical Technology, 9(4 Suppl), 103.

Stefanov, O. V. (2001). Doklinichni doslidzhennia likars'kyh zasobiv [Preclinical studies of drugs]. Avicena, Kyiv (in Ukrainian).

Sultana, R., McBain, A. J., \& O'Neill, C. A. (2013). Strain-dependent augmentation of tight-junction barrier function in human primary epidermal keratinocytes by Lactobacillus and Bifidobacterium lysates. Applied and Environmental Microbiology, 79(16), 4887-4894. 